\title{
Cytotoxicity and in vitro evaluation of whey protein-based hydrogels for diabetes mellitus treatment
}

\author{
S. J. Owonubi ${ }^{1}$ - E. Mukwevho ${ }^{2}$ B. A. Aderibigbe ${ }^{3} \cdot$ Neerish Revaprasadu $^{1}$ - E. R. Sadiku ${ }^{4}$
}

Received: 18 July 2018 / Accepted: 23 May 2019 / Published online: 30 May 2019

(c) The Author(s) 2019

\begin{abstract}
Obesity is the accumulation of excess body fat and the hallmark of type II diabetes mellitus, characterized by hyperglycemia. Glycemic control is very critical to reduce long-term vascular complications resulting from the progressive nature of hyperglycemia. In previous studies, thermally reduced graphene oxide ( $\mathrm{rGO}$ )-based hydrogel biocomposites were prepared and in vitro drug release studies confirmed their potential as a biodegradable-targeted drug delivery system. Thus, the in vitro biological evaluation of these rGO-based hydrogels was investigated. The hydrogels were encapsulated with chloroquine diphosphate $(\mathrm{CQ})$ and proguanil $(\mathrm{P})$ drugs to investigate potential of combination therapy. The non-toxic nature of the hydrogels was investigated by the use of the MTT assay against 3T3-L1 and c2c12 cell lines. 3T3-L1 pre-adipocytes were grown, differentiated and treated with the drug-encapsulated hydrogels to detect the effect on the adipose tissue cells by quantitative real-time polymerase chain reaction (qPCR) identifying gene expression levels by utilizing gene markers specific for diabetes and obesity: cpt-1, glut-4, acc1, pgc-1, mef2a and nrf-1 with comparison to positive control metformin. The cytoxicity studies confirmed non-toxic nature of the hydrogels; identified dosage of drugs encapsulated were effective within investigated treatment time and qPCR revealed an upregulation of CPT-1, GLUT-4, PGC-1, MEF2A and NRF-1 marker genes, but a downregulation of ACC-1 marker gene. The results from the expression of investigated genes suggest the anti-obesity potential of drugs released from the hydrogels. There were identified positive effects employing combination therapy, but further studies are required to ascertain the actual effect of the drugs in combination, by further varying the ratios of drugs (instead of the presented 1:1 ratio) employed. Statistically, the results from the individual drug release treatments were not significantly different from positive control metformin treatments, but the combination therapy investigation showed more promise.
\end{abstract}

Keywords Hydrogel biocomposite $\cdot$ Type II diabetes $\cdot$ Drug release $\cdot$ Adipocytes $\cdot$ Metformin $\cdot$ Gene markers

\section{Introduction}

S. J. Owonubi

oshesan@gmail.com

$\triangle$ E. Mukwevho

emmanuel.mukwevho@nwu.ac.za

1 Department of Chemistry, University of Zululand, KwaDlangezwa, KwaZulu Natal, South Africa

2 Department of Biochemistry, North-West University, Private Bag X2046, Mmabatho 2735, South Africa

3 Department of Chemistry, University of Fort Hare, Alice Campus, Alice, Eastern Cape, South Africa

4 Polymer Division, Institute of NanoEngineering Research (INER) and Department of Chemical, Metallurgical and Materials Engineering, Tshwane University of Technology, Staatsartillerie Rd, Pretoria West Campus, Pretoria, South Africa
In recent times, drug delivery systems are made of natural components, or synthetic materials, such as: carbon nanotubes, silica nanostructures, synthetic hydroxyapatite beads and polyelectrolyte microcapsules gaining significant importance due to their potential benefits in numerous cell-based therapies, tissue engineering techniques, lenses manufacture, cancer therapy, diabetic therapy and drug delivery [1-7]. Hydrogels are of particular interest for drug delivery applications due to their ability to address targeted drug delivery, in addition to their good biocompatibility, tunable network structure needed to control the diffusion of drugs and their ability to imbibe drugs within their mesh network structure [8-10]. Graphene oxide (GO) has gained popularity for its biomedical advancements $[11,12]$. The $\pi$ structure of 
graphene enables its interaction with hydrophobic drugs and these features make graphene materials ideal drug carriers, especially for hydrophobic drugs [13-16].

As a result of challenges with targeting causative substances using single drug molecules, combination of different drugs has been administered optimally and at different periods of the treatment [17-19]. Until recently, limited researches on dual drug delivery systems have so far provided positive results [5, 20-22].

Obesity is the accumulation of excess body fat and a prelude to type II diabetes mellitus (T2DM), a number of cardiovascular conditions: stroke, hypertension and certain forms of cancer [23]. Diabetes has become an ever increasing problem of pandemic proportions globally, with 425 million people estimated to be living presently with the condition, it is envisaged to increase by $55 \%$ by the year 2035 [24]. Diabetes is a heterogeneous endocrine disorder that is associated with hyperglycemia and there are two main types known, namely: type I diabetes mellitus and T2DM. Literature has shown that excessive lipid levels and their oxidation appear to play a major role in the development of insulin resistance and non-insulin-dependent diabetes (T2DM) [25, 26].

It has also been established that there is a link between the development of insulin resistance and pathogenesis of T2DM [27]. Physical inactivity, tissue inflammation, endoplasmic reticulum stress (ER-stress) in $\beta$-cells, oxidative stress, tissue lipid accumulation, aging, obesity and $\beta$-cell dysfunction are some of the factors known to be linked to insulin resistance which can progress to T2DM [28]. Oxidative stress and/or pro-inflammatory mediators are/is the most significant factor(s) [29]. The production of excess endogenous oxidative species causes oxidative stress, which can manipulate signaling pathways and damage cells [30, 31]. Therefore, the inhibition of oxidation stress aids in the management of insulin resistance and diabetes [32]. Insulin resistance and T2DM can be induced by pro-inflammatory mediators through stimulation of metabolic and/or various transcriptional mediated molecular pathways and oxidative stress [27]. Some studies have focused on oxidative stress mediators, notably pro-inflammatory cytokines such as adipocytokines, chemokines, tumor necrosis factor-alpha (TNF$\alpha$ ), interleukin-6 (IL-6) and interleukin-1 beta (IL-1 $\beta$ ) epigenetic factors, glucolipotoxicity, various transcriptional and metabolic pathways for the management of T2DM [33-37]. Metabolic pathways involving the regulation of lipids and carbohydrates depend on mitochondrial genes; similarly, glucose and fatty acids modulate the expression levels of a number of genes encoding metabolic enzymes in variety of cell types [38]. Thus, the insulin signaling pathway can be influenced and investigated by so many mediators and intermediates, such as: adenosine monophosphate-activated protein kinase (AMPK), carnitine palmitoyl transferase (CPT1), acetyl-coenzyme A carboxylase (ACC-1) and peroxisome proliferator-activated receptor gamma co-activator 1 (PGC1) [39]. Target genes responsible for fatty acids metabolism can help in the determination of candidate genes that can be potentially responsible for the alterations in insulin resistance and subsequently aid in the management of T2DM.

We recently reported on the in vitro release kinetics of antimalarials from whey protein-based hydrogel biocomposites containing whey protein isolate (WPI), reduced graphene oxide (rGO), and synthetic polymers in varied ratios [13], with suggestions that these rGO-containing hydrogels are $\mathrm{pH}$ sensitive and biodegradable for controlled release of bioactive agents.

This paper investigates the potential of these previously designed hydrogels to act as effective drug carriers to exploit combination therapy towards better management of T2DM. The prepared hydrogel biocomposites [13] were firstly subjected to toxicity analysis using the MTT assay and their drug release effects on target gene markers indicative of diabetes and obesity were investigated and recorded. In vitro release from drug loaded hydrogel biocomposite on 3T3-L1 adipocytes were performed. Comparison tests with positive control metformin and non-treated control were conducted, with impact on gene markers for diabetes and obesity recorded accordingly using the quantitative real-time polymerase chain reaction (qPCR).

\section{Experimental}

\section{Materials}

Hydrogel biocomposites prepared from previous work [13], metformin, streptomycin proguanil hydrochloride $(\mathrm{P})$, and chloroquine diphosphate (CQ) salt powders were purchased from Sigma Aldrich, South Africa. All cell culture reagents were purchased from Sigma-Aldrich (Pty) Ltd. (Johannesburg, RSA), qPCR reagents were purchased from Life Technologies, South Africa, while RNA clean concentrator-25 kit and 3T3-L1 adipocytes cell lines were purchased from Inqaba Biotechnical Industries, South Africa. MTT assay kit was supplied by Sigma Aldrich (Darmstadt, Germany).

\section{Drug encapsulation}

Drugs were loaded onto the previously designed hydrogel (GW3) containing both WPI $(0.05 \mathrm{~g})$ and rGO $(0.007 \mathrm{~g})$ according to our previous work, Table 1 [23]. Metformin, $\mathrm{P}$ and CQ were dissolved in distilled water and filtered into separate vials according to Table 2 . Hydrogels ( $20 \mathrm{mg}$ ) were soaked separately in each individual drug solution overnight at ambient temperature. The hydrogels were then rinsed with distilled water to get rid of any excess drug present on the surface of the hydrogels, and allowed to dry at ambient 
Table 1 Hydrogel design adapted from [23]

\begin{tabular}{llllllll}
\hline Hydrogel & WPI $(\mathrm{g})$ & $\begin{array}{l}\text { MBA } \\
(65 \mathrm{mM}) \\
(\mathrm{mL})\end{array}$ & $\begin{array}{l}\text { KPS } \\
(37 \mathrm{mM}) \\
(\mathrm{mL})\end{array}$ & Acrylamide $(\mathrm{g})$ & $\begin{array}{l}\text { TMEDA } \\
(86.1 \mathrm{mM}) \\
(\mathrm{mL})\end{array}$ & $\begin{array}{l}\text { NaOH } \\
(0.05 \mathrm{M}) \\
(\mathrm{mL})\end{array}$ & RGO (g) \\
\hline GW1 & - & 1 & 1 & 0.5 & 1 & - & - \\
GW2 & 0.11 & 1 & 1 & 0.5 & 1 & 1 & - \\
GW3 & 0.05 & 1 & 1 & 0.5 & 1 & 1 & 0.007 \\
GW4 & - & 1 & 1 & 0.5 & 1 & 1 & 0.007 \\
\hline
\end{tabular}

Table 2 Drug load concentration

\begin{tabular}{lc}
\hline Hydrogel & $\begin{array}{l}\text { Mass of } \\
\text { drug (ng) }\end{array}$ \\
\hline P1 & 20 \\
P2 & 40 \\
P3 & 60 \\
P4 & 80 \\
P5 & 100 \\
CQ1 & 20 \\
CQ2 & 40 \\
CQ3 & 60 \\
CQ4 & 80 \\
CQ5 & 100 \\
\hline
\end{tabular}

temperature for 5 days. The percentage encapsulation efficiency of CQ and P onto the hydrogels was determined spectrophotometrically.

\section{Cell growth}

Frozen cells were removed from $-80{ }^{\circ} \mathrm{C}$, thawed at $37{ }^{\circ} \mathrm{C}$ and grown for 1 week in $10-\mathrm{mL}$ culturing media, growth medium (90\% Dulbecco's Modified Eagle's medium (DMEM), 10\% Fetal calf serum FSC and 1\% streptomycin) at $37{ }^{\circ} \mathrm{C}$ in $95 \%$ humidity with $5 \% \mathrm{CO}_{2}$. Thereafter, cells were split, using the following procedure:

Growth media, Phosphate-buffered saline (PBS) and Trypsin were pre-heated at $37^{\circ} \mathrm{C}$, media were decanted and plates were washed with PBS. One microliter of trypsin was then added to each plate and incubated for $5 \mathrm{~min}$ at $37^{\circ} \mathrm{C}$. Five microliters of media was then added to plates and transferred cells to centrifuge tubes. Cells were then centrifuged at $2000 \mathrm{rpm}$ for $3 \mathrm{~min}$. Media were decanted and appropriate amount of media was added depending on number of plates and pellet was re-suspended. One microliter of cells was transferred to each plate together with $9 \mathrm{~mL}$ of growth media and incubated at $37{ }^{\circ} \mathrm{C}$ in $95 \%$ Humidity with $5 \% \mathrm{CO}_{2}$ (Fig. 1). After cell growth, cells were allowed to differentiate in $97 \%$ humidity in DMEM, 1\% streptomycin and 2\% Horse Serum (HS) for 1 week (Fig. 2).

\section{Cytotoxicity studies}

An in vitro cytotoxicity study was performed on 3T3-L1 and c2c12 cell lines using 3-(4,5-dimethylthiazol-2-yl)-2,5-diphenyltetrazolium bromide (MTT) assay to assess biological safety of hydrogel. The cells were grown for $48 \mathrm{~h}$ and differentiated for $72 \mathrm{~h}$ in 96-well plates in complete media without antibiotics. After the cells were differentiated to allow for the expression of the required phenotypic characteristics, the cells were treated using the plain hydrogels to ascertain possible toxicity to the cells. The treatments were performed in triplicates, with $\sim 2.0-\mathrm{mg}$ gels and for a 72-h time period. The dose(s) of drugs for the MTT assay was(were) established by performing preliminary studies, explained in the results section with varying doses of drugs as shown in Table 2. The viability of the cells was quantified
Fig. 1 3T3-L1 preadipocytes cell growth viewed under the phase contrast light microscope a 4 days b 7 days
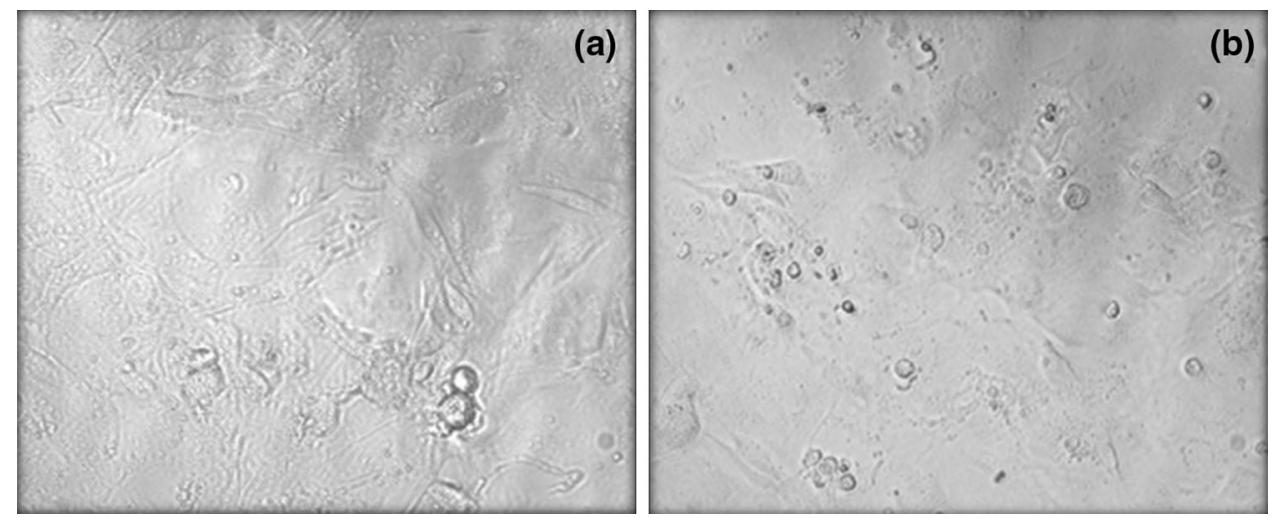
Fig. 2 Differentiation of 3T3-L1 cells viewed under the phase contrast light microscope a 4 days $\mathbf{b} 7$ days
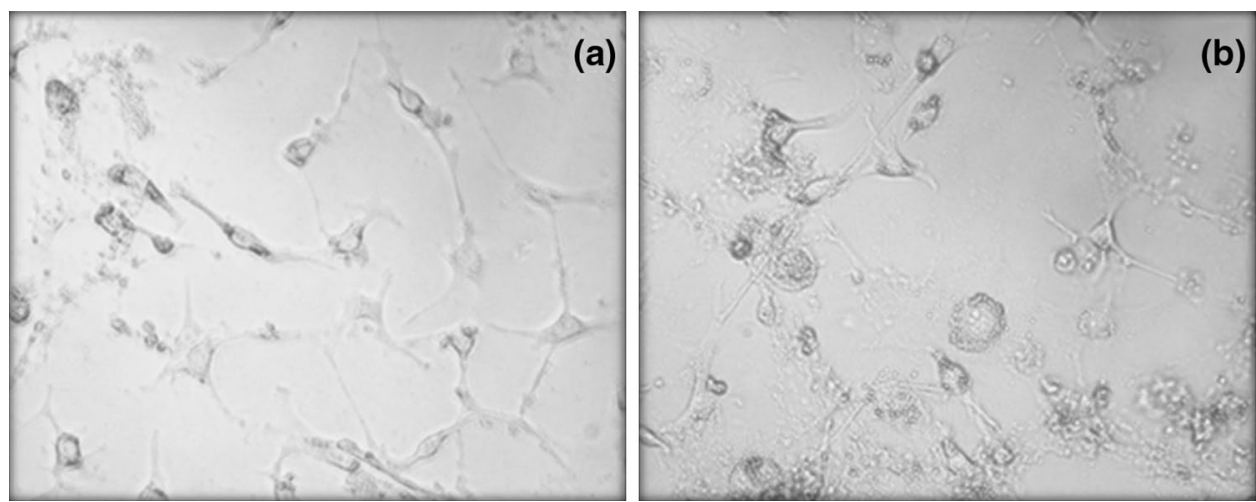

by colorimetric assay which showed the MTT reduction by viable cells, as evident in published literatures [40, 41] using a Thermofisher Multiskan GO microplate spectrophotometer (Germering, Germany) and absorbance measured at a wavelength of $540 \mathrm{~nm}$.

\section{Quantitative real-time polymerase chain reaction (qPCR)}

The qPCR was used to identify the expression of genes after treatment and spicing the cells. After treatment, a 4-h incubation with un-supplement DMEM was performed, $1 \mathrm{~mL}$ of QIAzol lysis reagent was added to each plate of cells and the cells were spliced and transferred to Eppendorfs, followed by a 5-min incubation on ice. RNA was then extracted and isolated as instructed by RNA clean and Concentrator-25 Kit; this consisted of the following procedure:

Cells were centrifuged at $12,000 \times g$ for $15 \mathrm{~min}$ at $4{ }^{\circ} \mathrm{C}$, cells were decanted into a new tube and $110 \mu \mathrm{L}$ of chloroform was added to each tube. Cells were then vortexed for few seconds and incubated on ice for $3 \mathrm{~min}$, followed by a 15 -min centrifugation at $12,000 \times g$ and $4{ }^{\circ} \mathrm{C}$. Upper aqueous solution was transferred to a $2-\mathrm{mL}$ centrifuge tube $(500 \mu \mathrm{L})$ and topped up to a final volume of $2 \mathrm{~mL}$ with RNA binding buffer. The solution was then split into two by removing and transferring $1 \mathrm{~mL}$ of solution to a new tube, $1 \mathrm{~mL}$ of ethanol was then added and vortexed. One microliter of solution was transferred to a collection tube and centrifuged for $1 \mathrm{~min}$ at $12,000 \times g, 4{ }^{\circ} \mathrm{C}$ (step was repeated 4 times) and flow through was discarded.

The sample was then washed with $400-\mu \mathrm{L}$ wash buffer, centrifuged at $12,000 \times \mathrm{g}$ for $30 \mathrm{~s}$ (flow through was discarded). Five microliters of DNase, 5- $\mu \mathrm{L}$ DNase reaction buffer and $40-\mu \mathrm{L}$ wash buffer were then added and sample was incubated at $37^{\circ} \mathrm{C}$ for $30 \mathrm{~min}$. Four hundred microliters of RNA prep buffer was then added and centrifuged at $12,000 \times g$ for $1 \mathrm{~min}$; flow through was discarded and followed by the addition of $800 \mu \mathrm{L}$ wash buffer and centrifuged at $12,000 \times g$ for $30 \mathrm{~s}$. The wash step was repeated with 400 $\mu \mathrm{L}$ wash buffer and flow through was discarded. Emptied
Column was then centrifuged at $12,000 \times g$ for 2 min and transferred to a new tube to which $40 \mu \mathrm{L}$ of DEPC water was added and left to stand for $1 \mathrm{~min}$ at room temperature and followed by centrifugation at $10,000 \times g$ for $30 \mathrm{~s}$. Nanodrop 1000 was then performed with each of the sample using $1.5 \mu \mathrm{L}$ of sample to determine RNA concentration.

RNA integrity was tested by performing DNA agarose gel electrophoresis with a $1 \%$ Agarose gel dissolved in $100 \mathrm{~mL}$ of 10× TBE buffer (108-g Tris, 55-g Boric acid and 40-mL $0.5 \mathrm{M}$ EDTA dissolved in $1 \mathrm{M} \mathrm{NaOH}$ for $1 \mathrm{~L}, \mathrm{pH}$ 8.3). Once the gel was cooled, $5 \mu \mathrm{L}$ of GR Green was added to the gel and the gel was poured and left to set. Samples were prepared using 1- $\mu \mathrm{g}$ RNA (treated sample), $2-\mu \mathrm{L}$ loading buffer and topped up with DEPC water, to a final volume of $10 \mu \mathrm{L}$. $5 \mu \mathrm{L}$ of Hyperladder I and samples were loaded and the gel was run at $90 \mathrm{~V}$ for $1 \mathrm{~h}$ with TBE buffer. RNA Integrity was then evaluated and photographed with Chemidoc TMMP.

Complimentary DNA (c-DNA) was prepared by the addition of $1-\mu \mathrm{L}$ oligo(dT), 1- $\mu \mathrm{L}$ Random Hexamer and $1-\mu \mathrm{L}$ dNTP $(10 \mathrm{mM})$ to $3-\mu \mathrm{g}$ mRNA and made to a final volume of $13 \mu \mathrm{L}$ with DEPC water. Samples were then spun down and incubated at $65{ }^{\circ} \mathrm{C}$ for $5 \mathrm{~min}$, followed by $1 \mathrm{~min}$ incubation on ice. To each sample, $4 \mu \mathrm{L}$ of $5 \times$ First-strand buffer, $1 \mu \mathrm{L}$ DTT (0.1 M) and $1 \mu \mathrm{L}$ Superscript was added; samples were then spun down and followed by incubations for $5 \mathrm{~min}$ at $25{ }^{\circ} \mathrm{C}, 60 \mathrm{~min}$ at $55^{\circ} \mathrm{C}$ and $15 \mathrm{~min}$ at $70^{\circ} \mathrm{C}$. qPCR was performed and the reaction mix used for this procedure is indicated in Table 3.

Table 3 Reaction mixture for qPCR master mix make up

\begin{tabular}{lll}
\hline Reagents & Volume & Concentration \\
\hline 2× Sensifast & $10 \mu \mathrm{L}$ & $1 \times$ \\
$10-\mu \mathrm{M}$ forward primer & $0.8 \mu \mathrm{L}$ & $400 \mathrm{nM}$ \\
$10-\mu \mathrm{M}$ reverse primer & $0.8 \mu \mathrm{L}$ & $400 \mathrm{nM}$ \\
Template & $2.6 \mu \mathrm{L}$ & \\
Milli-Q water & Use to make up to final \\
& \multicolumn{2}{c}{ volume required } \\
\hline
\end{tabular}


A master mix was prepared according to Table 3 for each gene, depending on the amount of samples and $17.4 \mu \mathrm{L}$ of reaction mixture was added to each, together with $2.6 \mu \mathrm{L}$ of appropriate template, for non-template control $2.6 \mu \mathrm{L}$ of Milli-Q water was added, and for standards $2.6 \mu \mathrm{L}$ of each dilution was added to make up the standards. $10-\mu \mathrm{M}$ primers were prepared from $100-\mu \mathrm{M}$ primer stock and standards were prepared with a serial dilution $1 \times-10,000 \times$, whereby $1 \times$ was prepared by the combination of $2 \mu \mathrm{L}$ of each template.

qPCR was performed in triplicate, using BIO-RAD CFX Connect Real-Time System PCR machine by employing SensiMix SYBER No-ROX kit, according to cycle conditions in Table 4 and forward and reverse primers were used for the process, according to Table 5 to amplify the mouse genes; CPT-1, ACC-1, NRF-1, MEF2A, GLUT4 and PGC1 , with actin as reference gene.

\section{Treatment of cells}

After the cells were differentiated to express the required phenotype, the cells were treated. A preliminary study to assist and evaluate the feasibility, time, adverse events of the experiment using a single gene to allow for possible improvements upon the study design prior to investigating other genes was performed. This pilot study was initiated

Table 4 Quantitative real-time PCR (qPCR) cycles and conditions

\begin{tabular}{llll}
\hline Cycles & Conditions & & \\
\cline { 2 - 4 } & Temperature $\left({ }^{\circ} \mathrm{C}\right)$ & Time & Process \\
\hline 1 & 95 & $2 / 10 \mathrm{~min}$ & Polymerase activation \\
40 & 95 & $5 \mathrm{~s}$ & Denaturation \\
N/A & $60-95$ & $10 \mathrm{~s}$ & Annealing \\
N/A & 72 & $5-20 \mathrm{~s}$ & Extension \\
\hline
\end{tabular}

to identify the optimum concentration of drug required to effectively treat the cells and then, a time-dependent study was performed to identify the optimum time duration for the treatments. Both preliminary/pilot studies employed positive control metformin treatments $(2 \mathrm{ng} / \mathrm{mL})$ and untreated negative controls.

To this effect, the initial efficacy of the treatment was investigated by its influence on the expression of the CPT-1 gene marker only, by recording the expression ratio in comparison to the controls for each treatment. These were achieved by:

\section{Identification of optimum drug concentration pilot study}

This study was performed to ascertain the most effective concentration of the drugs for treatment, the treatment concentration that showed significant beneficial effects when compared to control treatments. The cells were grown for about 1 week in 10-mL culturing media, differentiation followed accordingly as described in the previous section. The differentiated cells were treated by inserting each hydrogel loaded with drugs according to Table 2 into day 6 or 7 differentiated cells and left to stay; after $24 \mathrm{~h}$, the gels were removed and the cells were spliced for the identification of levels of cpt-1 gene expressed and compared to control treatments.

\section{Time-dependent pilot study}

The time-dependent study was performed to establish the optimal timespan for the cell treatment enough to induce optimal CPT-1 gene expression in vitro. To achieve this, the cells were grown and differentiated as explained in previous sections (Figs. 1,2) showing the cells viewed under the light microscope. This was followed by the treatment with
Table 5 Primers sequences for the amplification of the genes used for qPCR

\begin{tabular}{|c|c|c|}
\hline Gene type & Primer type & Primer sequence \\
\hline \multirow[t]{2}{*}{ Actin (reference gene) } & Forward & 5'-GGCACCACACTTTCTACAATG-3' \\
\hline & Reverse & 5'-GGGGTGTTGAAGGTCTCAAAC-3' \\
\hline \multirow[t]{2}{*}{ ACC-1 } & Forward & 5'-TGCCTATGAACTCAACAGCG-3' \\
\hline & Reverse & 5'-ACATTCTGTTTAGCGTGGGG-3' \\
\hline \multirow[t]{2}{*}{ MEF2A } & Forward & 5'-GTGTACTCAGCAATGCCGAC-3' \\
\hline & Reverse & 5'-ACCCCTGAGATAACTGCCCTC-3' \\
\hline \multirow[t]{2}{*}{ GLUT4 } & Forward & 5'-AAGATGGCCACGGAGAGAG-3' \\
\hline & Reverse & 5'-GTGGGTTGTGGCAGTGAGTC-3' \\
\hline \multirow[t]{2}{*}{ PGC-1 } & Forward & 5'-CATTTGATGCACTGACAGATGGA-3' \\
\hline & Reverse & 5'-CCGTCAGGCATGGAGGAA-3' \\
\hline \multirow[t]{2}{*}{ NRF-1 } & Forward & 5'-ATGGAGGAACACGGAGTGAC-3' \\
\hline & Reverse & 5-GCTTTTTGGGACAGTGAAAT-3' \\
\hline \multirow[t]{2}{*}{ CPT-1 } & Forward & 5'-CCAGGCTACAGTGGGACATT-3' \\
\hline & Reverse & 5'-GAACTTGCCCATGTCCTTGT-3' \\
\hline
\end{tabular}


the drug encompassed (Table 2) within the carrier vehicle for a maximum of $72 \mathrm{~h}$, and compared to control treatments.

\section{Evaluation of polymeric hydrogels as effective anti-obesity drug carriers}

Hydrogels loaded with drugs according to Table 2 were investigated for their effect on specific marker gene expression related to anti-obesity on 3T3-L1 pre-adipocytes cell lines, using quantitative real-time PCR (qPCR). The optimal concentration and time identified by the pilot studies were employed in the identification of the expression of marker genes in relation to treatment with P and CQ drugs when compared with that of the controls. Additionally, the effect of combining both drugs together (P and CQ incorporated within gels in 1:1 ratio combination), a form of combined therapy was also investigated in order to recognize the effect on the cell lines.

\section{Statistical analysis}

One-way analysis of variance was used to determine statistical significance. The results are expressed as means \pm the standard error of the mean. $p$ values $<0.05$ were considered statistically significant. All statistical analysis was performed using Graph Pad prism software version 6.0 (GraphPad Software, Inc., La Jolla, CA, USA).

\section{Results}

\section{Cell growth}

The growth of the 3T3-L1 cell lines was viewed under a phase contrast light microscope, as shown in Fig. 1a 4-day cell growth and Fig. 1b 7-day cell growth. Cell differentiation was observed under the phase contrast light microscope after 1 week of cell growth, as shown in Fig. 2a 4 days and Fig. $2 b 7$ days.

\section{Cytotoxicity tests}

The hydrogels were shown to exhibit non-toxic properties to both the 3T3-L1 and c2c12 cell lines. Percentage cell viability after the treatments using MTT assay was $>85 \%$ across both cell lines triplicate studies (Fig. 3). There was no significant effect of the hydrogels on the percentage cell survival against both cell lines used in the study in comparison to control treatments.

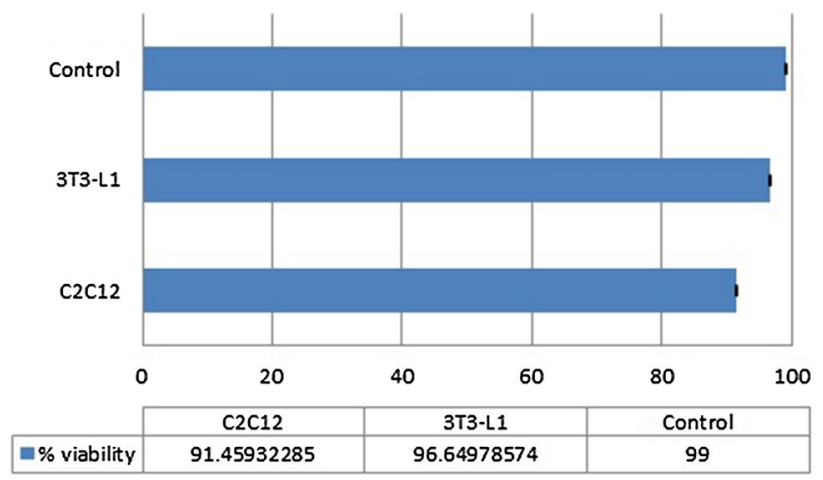

Fig. 3 Cell viability study: was determined by the use of MTT Assay

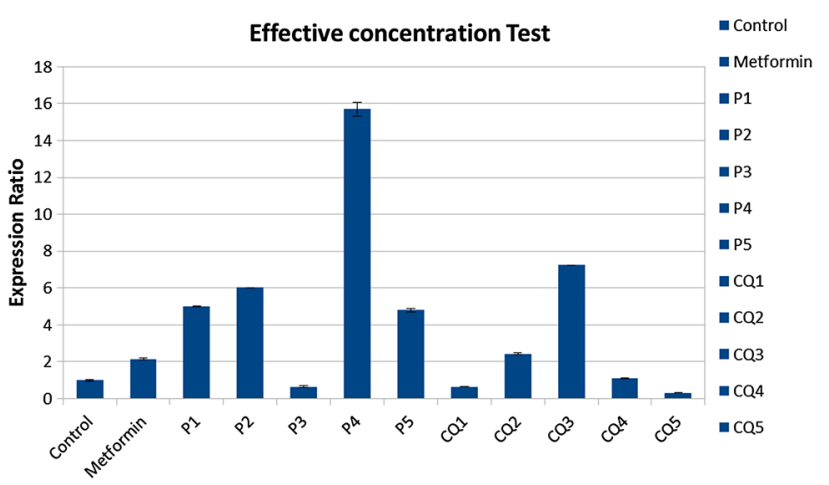

Fig. 4 Drug concentration studies: CPT-1 gene expression in 3T3-L1 cell lines to identify the effective optimum levels from the varied concentrations used

\section{Treatment of cells}

Identification of optimum drug concentration revealed P4 (80 ng) to have the most significant effect, with more than tenfold increase recorded, while CQ3 (60 ng) showed an increase in cpt- 1 gene expression of more than eightfold compared to untreated control (Fig. 4). The time-dependent pilot study showed $\mathrm{P} 4$ performed optimally at $48 \mathrm{~h}$ with about onefold increase and CQ3 at $72 \mathrm{~h}$ revealing about twofold increase compared to the non-treated control. There was a gradual increase in cpt-1 gene expression on treatment with $\mathrm{P}$, but at $48 \mathrm{~h}$, this expression was found to decline as seen at the $72 \mathrm{~h}$. However with CQ, the expression of the cpt-1 gene increases continuously till an optimum time at 72 h (Fig. 5).

\section{Evaluation of polymeric hydrogels as anti-obesity agents}

Mature adipocytes were treated with $\mathrm{P}$ for $48 \mathrm{~h}$ and CQ for $72 \mathrm{~h}$, adapted from the pilot study findings. The treatment with combination of both drugs was for $60 \mathrm{~h}$, as the optimum 


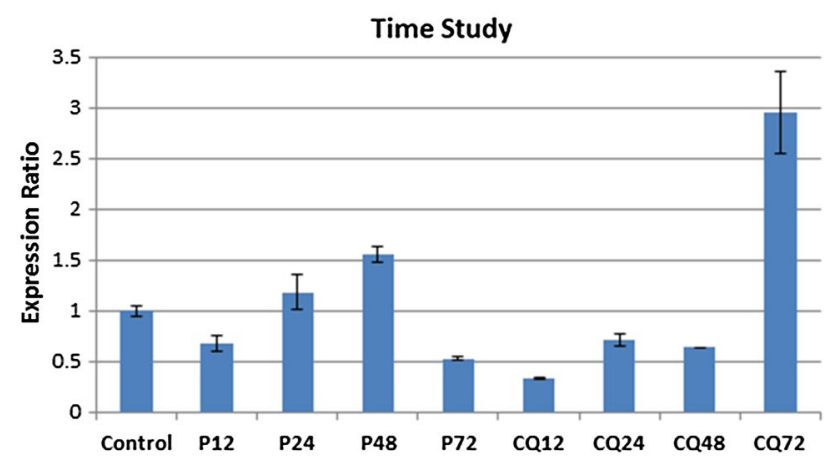

Fig. 5 Time dependent studies: CPT-1 gene expression in 3T3-L1 cell lines in order to ascertain the optimal time of action of the CQ3 and $\mathrm{P} 4$ drugs on treatment

\section{1}

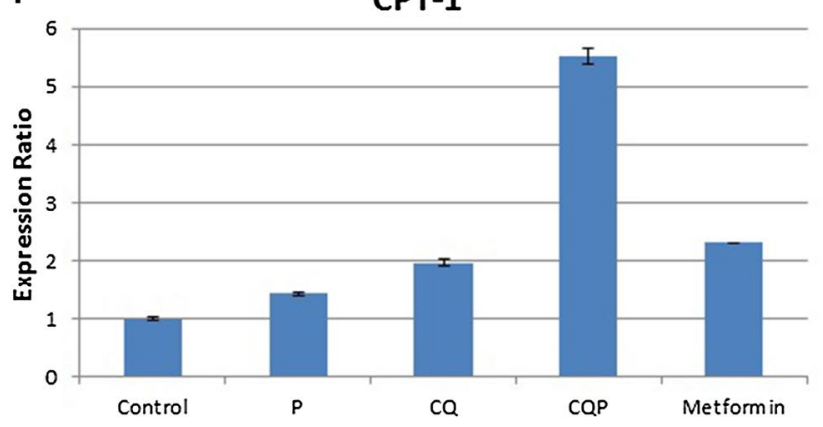

3

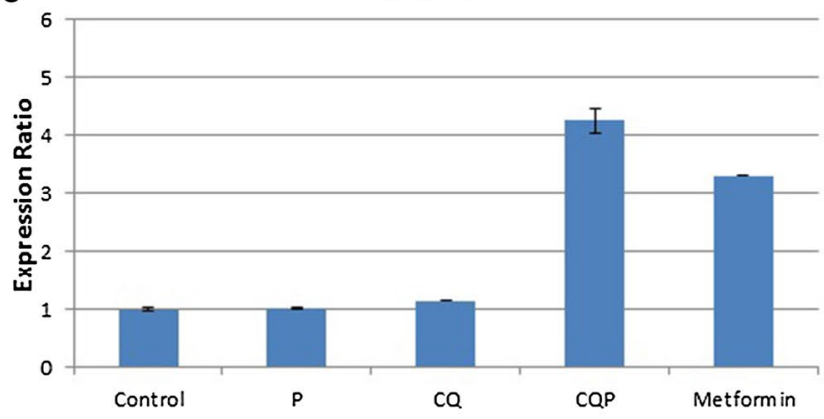

5

GLUT-4

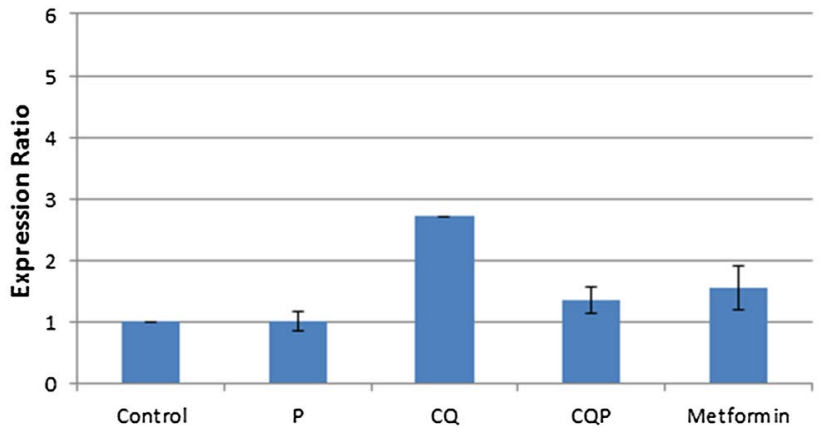

Fig. 61 Expression of CPT-1 gene after treatment of 3T3-L1 cells. 2 Expression of PGC-1 gene after treatment of 3T3-L1 cells. 3 Expression of NRF-1 gene after treatment of 3T3-L1 cells. 4 Expres- time of action of drug $\mathrm{P}$ was hypothesized to be $\sim 60 \mathrm{~h}$ and these results are reported in terms of expression ratio and the average of both optimal timestamps was $\sim 60 \mathrm{~h}$. Thus, for all investigations, $\mathrm{P}(80 \mathrm{ng}), \mathrm{CQ}(60 \mathrm{ng})$ and CQP (80 ng $\mathrm{P}+60 \mathrm{ng} \mathrm{CQ}$ ) were utilized to identify the drug treatments as potential anti-obesity agents.

Carnitine palmitoyl transferase (CPT-1) After cell diferentiation, the assessment of CPT-1 after the treatment of 3T3L1 with drug P, CQ and combination of CQP was investigated (Fig. 6.1). This shows $\sim 0.5$ fold increase for drug $P$, while onefold increase was observed for CQ when compared to untreated control. For both $\mathrm{P}$ and $\mathrm{CQ}$, metformin performed better, with upregulation of $\sim 1.5$ folds compared

2

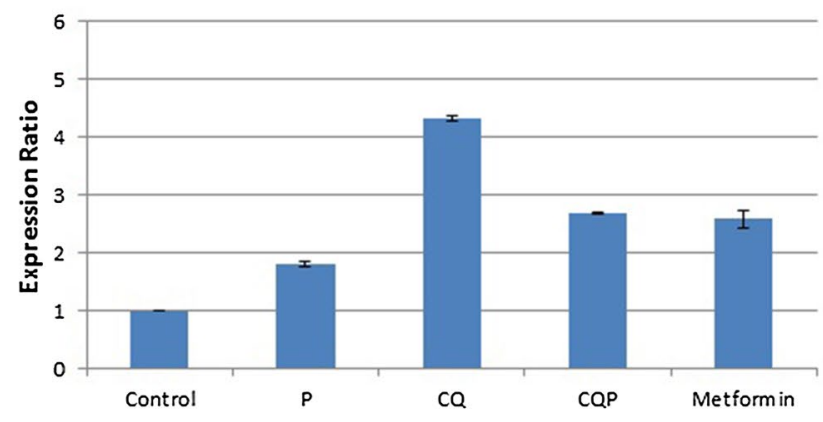

4

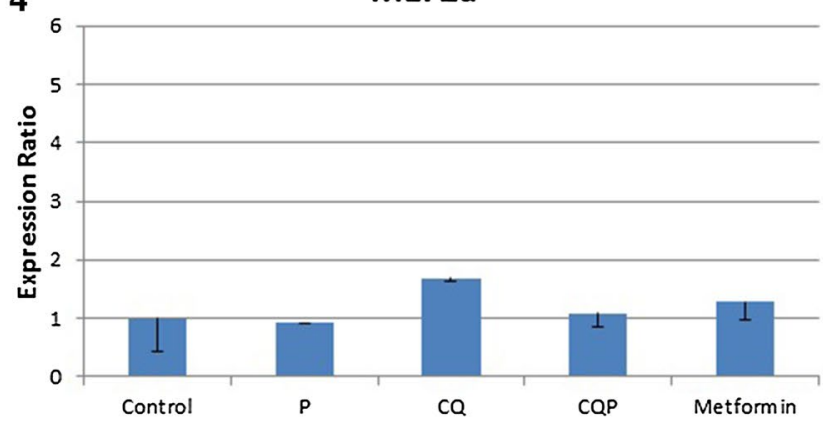

6



sion of MEF2a gene after treatment of 3T3-L1 cells. 5 Expression of GLUT-4 gene after treatment of 3T3-L1 cells. 6 Expression of ACC-1 gene after treatment of 3T3-L1 cells 
to untreated control. The combination CQP showed the best upregulation fold increase $\sim$ sixfold when compared to the untreated control, but $\sim$ threefold when compared to positive control metformin.

\section{Proliferator-activated receptor gamma coactivator} 1(PGC-1) Figure 6.2 reveals both drugs representing positive expression of the PGC-1 gene, but in combination, the expression level drops. $\mathrm{P}$ shows a onefold increase, while CQ shows a twofold increase when compared to metformin. But in combination (CQP), this increase becomes relatively insignificant in comparison to positive treatment metformin.

Nuclear respiratory factor 1 (NRF1) Results from Fig. 6.3 show that the expression of NRF-1 gene is not significant in the treatment with the drugs individually, but in combination (CQP), there is onefold increase when compared to positive control metformin, but $\sim$ threefold increase when compared to untreated control.

Myocyte enhancing transcription factor (MEF2A) The expression of MEF2A showed that there is no substantial difference in the expression of the drugs (Fig. 6.4). However, drug CQ is most significant with onefold increase when compared to the positive control metformin.

Glucose transporter (GLUT4) Figure 6.5 revealed the upregulation of the expression of glucose transporter gene (GLUT4) after treatment, with the most significant fold increase of 2.5 by CQ compared to untreated control, onefold increase by $\mathrm{P}$, and $\sim 1.5$-fold increase by CQP and metformin.

Acetyl CoA carboxylase (ACC-1) The expression investigated after treatment revealed in Fig. 6.6, the downregulation of ACC-1 gene and it was observed most significantly with the treatment $\mathrm{CQ}$ with 0.5-fold decrease when compared to the untreated control and metformin.

\section{Discussions}

During cell growth, the lipid droplets forming in the early days of cell growth of the pre-adipocytes were evident and became more widespread as the number of cells increased with more lipid droplets forming (Figs. 1, 2). The welldefined network of cells can be appreciated as the cells were differentiated ad lipid droplets formed.

The cytotoxicity study confirmed that the plain hydrogels had no toxic effect on the growth and differentiation of both 3T3-L1 and c2c12 cell lines in vitro, with the high percentage survival of the cells with the hydrogels present within their media for up to $72 \mathrm{~h}$. The pilot studies revealed the optimum concentration of action on sample gene marker CPT-1 to be P4 (80 ng) and CQ3 (60 ng); while the optimum timespan for release from the polymer hydrogels loaded was P4 (48 h) and CQ3 (72 h). With regards to this experiment, the hypothesized time for the combined therapy CQP was deemed to be the average $60 \mathrm{~h}$.

Carnitine palmitoyl transferase (CPT)- 1 encoded by cpt- 1 gene controls the rate-limiting step in the mitochondrial lipid oxidation. Reports have shown that the upregulation of CPT-1 can result in increased oxidative capacity of the mitochondria by reducing lipid accumulation and obesity [42-45]. Impairment of this oxidation has been associated with diabetes and obesity. Thus, the reported upregulation by all the treatments is encouraging, but the level highlighted by CQP is excellent, as it about double that of metformin treatment, the existing treatment standard. PGC-1 is the transcription co-activator that interacts with a broad range of transcription factors that are involved in a wide variety of biological responses including adaptive thermogenesis, mitochondrial biogenesis, glucose and fatty acid metabolism, fiber-type switching in skeletal muscle and heart development. Literature reveals that expression of PGC-1 is down-regulated in muscles of type 2 diabetic subjects [43, 44]; hence, its upregulation after treatment shows a trend towards management of the diseased condition. The upregulation observed in all treatments is highlighted with CQ treatment, having the highest fold of expression, but when combined with $\mathrm{PQ}$, the combination seems to have a negative effect on the treatment, leaving CQP treatment having about the same effect as metformin treatments. Nuclear respiratory factor 1 (NRF1) serves as a transcription factor that activates the expression of a wide range of nuclear genes essential for mitochondrial biogenesis and function [46]. Majority of lipid metabolism especially oxidation takes place in the mitochondria, an organelle regulated by the NRF-1, as such it controls and regulates most of these genes involved in lipid oxidation, e.g., CPT-1. The upregulation of NRF-1 is expected of effective T2DM treatments and this is observed most effectively in CQP treatment, with more than threefold increase in expression levels compared to untreated control and considerably better expressed than metformin. The mef2a isoform is responsible for GLUT4 upregulation under certain conditions [47, 48]. It has been identified that the MEF2A regulates the GLUT-4 gene encoded by MEF2A gene, which binds to its cis-elements as a hetero-dimer (MEF2A/D) resulting in GLUT-4 expression $[47,48]$. Hence, as indicated by [33], the downregulation of GLUT-4 will also result into a downregulation of MEF2A and invariably be associated with diabetes. The upregulation of MEF2A is evident from the results; although when compared to the previous genes, it is the lowest level that has been observed. CQ treatment is expressed the most, but 
metformin and CQP treatments are almost on the same level, but these show that the treatment was effective.

GLUT-4, a glucose transporter from a compartment within the cell to plasma membrane performs glucose transportation, utilization and glucose homeostasis in the muscle and adipose tissue. It has been indicated that a downregulation of Glut-4 gene expression present in adipocytes can be associated with diabetes [49]. Its upregulation confirms effective treatment of T2DM, and this is observed by all the treatments, although $\mathrm{P}$ treatment was the least effective, CQ treatment was observed to be expressed $\sim$ twofold higher than untreated control and $\sim 1$ more than metformin treatment. The combined treatment had levels of expression closely to that of the metformin treatment. Acetyl CoA carboxylase encoded by ACC-1 gene catalyzes lipid synthesis. It is important to mention that fat synthesis which may lead to obesity and insulin resistance blocks glucose transport by GLUT4 in insulin resistance cases and lipid accumulation through the action of ACC may lead to the accumulation of lipid species like ceramide, long chain fatty acids which inhibits GLUT4 translocation. ACC which catalyzes fat synthesis opposes the action of CPT-1 enzymes for fat Oxidation. Both glucose transport and lipids occurs in parallel hence GLUT4 as a transporter of glucose will go hand in hand with lipid as both are energy sources for ATP generation. Therefore, controls of lipid metabolism and glucose are mutually exclusive and have close relationship. Hence, the desire is for effective transportation of glucose happening together with fat oxidation through CPT-1. However, this can be inhibited by the action of ACC resulting in unwanted fat synthesis in the cytosol as both glucose and lipid are together broken down in the mitochondria to produce ATP but ACC can inhibit this action.

Reports have shown that the downregulation of ACC-1 can result in increased oxidative capacity of the mitochondria by reducing lipid accumulation and obesity [42-44]. Thus, downregulation of this gene is indication of effective treatment of T2DM. CQ treatment was reportedly the most effective in the ACC-1 gene expression; this was closely followed by $\mathrm{P}$ treatment and metformin treatments. The combined CQP treatment was the least effective on the ACC-1 gene expression and it could be a condition where the effect of combining both drugs did not have a synergistic effect on the treatment. These findings confirm the possibility of CQ as an anti-obesity drug, which has been reported by other researchers [50], but the known side-effect, makes its use to be shunned.

\section{Conclusion}

The aim of this research was to confirm the non-toxic nature of prepared polymer hydrogels and utilize them to deliver antimalarials, a form of combined therapy, for the investigation of alleviation of obesity using 3T3-L1 cell lines. The effectiveness of each treatment was identified in vitro in comparison to positive control metformin, using qPCR, gene markers specific for diabetes and obesity: CPT-1, GLUT-4, ACC1, PGC-1, MEF2A and NRF-1 gene expression ratios were recorded and compared.

In vitro cytotoxicity studies were performed with the already prepared hydrogel biocomposites on mature 3T3-L1 and $\mathrm{c} 2 \mathrm{c} 12$ cells using the MTT assay kit with no significant toxicity to the cells recorded. The marker genes expression ratios were in line with literature; CPT-1 gene expression ratio was high when treated with combination CQP, PGC-1 gene showed CQ treatment as the drug composition with superior effect, NRF-1 gene expression was found to be the most significant with the combination drug (CQP) when compared to metformin, MEF2A gene showed the highest expression ratio with CQ drug, while the downregulation of ACC-1 gene was the most efficient with treatment by CQ drug. It is known that CQ in the past used to be used for the treatment of diabetes, but as a result of the possibility of hypoglycaemia during its usage, its usage has been limited.

In summary, the effect of combination therapy was found to have a marked effect on the expression levels in some of the marker genes; while in some others, the influence of drug P lowered the expression levels. It was observed that there are positive effects when combination therapy is employed, but further studies will be required to ascertain the actual effect of the drugs in combination, by possibly varying increasing the ratios of drugs (instead of the present 1:1 ratio) employed to further perform investigations.

Acknowledgement The financial support of Medical Research Council (MRC), National Research Foundation (NRF) and University of Zululand (UZ) South Africa towards this research are hereby acknowledged. The views and opinions expressed in this manuscript are those of the authors and not of MRC, UZ or NRF. SJO thanks the National Research Foundation (NRF) for a postdoctoral fellowship and funding under South African Research Chair for Nanotechnology.

\section{Compliance with ethical standards}

Conflict of interest The authors report no conflict of interest.

Open Access This article is distributed under the terms of the Creative Commons Attribution 4.0 International License (http://creativeco mmons.org/licenses/by/4.0/), which permits unrestricted use, distribution, and reproduction in any medium, provided you give appropriate credit to the original author(s) and the source, provide a link to the Creative Commons license, and indicate if changes were made.

\section{References}

1. Zhang H, Mardyani S, Chan WC, Kumacheva E (2006) Design of biocompatible chitosan microgels for targeted $\mathrm{pH}$-mediated 
intracellular release of cancer therapeutics. Biomacromol 7(5):1568-1572

2. Ramachandran S, Flynn P, Tseng Y, Yu YB (2005) Electrostatically controlled hydrogelation of oligopeptides and protein entrapment. Chem Mater 17(26):6583-6588

3. Li CL, Martini LG, Ford JL, Roberts M (2005) The use of hypromellose in oral drug delivery. J Pharm Pharmacol 57(5):533-546

4. Gaharwar AK, Peppas NA, Khademhosseini A (2014) Nanocomposite hydrogels for biomedical applications. Biotechnol Bioeng 111(3):441-453

5. Fasiku V, Aderibigbe B, Sadiku E, Lemmer Y, Owonubi S, Ray S, Mukwevho E (2018) Polyethylene glycol-gum acacia-based multidrug delivery system for controlled delivery of anticancer drugs. In: Polymer bulletin. pp 1-27

6. Mundargi RC, Rangaswamy V, Aminabhavi TM (2011) pH-Sensitive oral insulin delivery systems using Eudragit microspheres. Drug Dev Ind Pharm 37(8):977-985

7. Agnihotri SA, Mallikarjuna NN, Aminabhavi TM (2004) Recent advances on chitosan-based micro-and nanoparticles in drug delivery. J Control Release 100(1):5-28

8. Hu X, Ma L, Wang C, Gao C (2009) Gelatin hydrogel prepared by photo-initiated polymerization and loaded with TGF- $\beta 1$ for cartilage tissue engineering. Macromol Biosci 9(12):1194-1201

9. Owonubi S, Agwuncha S, Mukwevho E, Aderibigbe B, Sadiku E, Biotidara O, Varaprasad K (2017) Application of hydrogel biocomposites for multiple drug delivery. Handbook of composites from renewable materials. Polym Compos 6:139

10. Mundargi RC, Rangaswamy V, Aminabhavi TM (2011) Poly (N-vinylcaprolactam-co-methacrylic acid) hydrogel microparticles for oral insulin delivery. J Microencapsul 28(5):384-394

11. Hu J, Zhang G, Liu S (2012) Enzyme-responsive polymeric assemblies, nanoparticles and hydrogels. Chem Soc Rev 41(18):5933-5949

12. Yan J-L, Chen G-J, Jun C, Wei Y, Xie B-H, Yang M-B (2012) Functionalized graphene oxide with ethylenediamine and 1, 6-hexanediamine. New Carbon Mater 27(5):370-376

13. Owonubi S, Aderibigbe B, Mukwevho E, Sadiku E, Ray S (2018) Characterization and in vitro release kinetics of antimalarials from whey protein-based hydrogel biocomposites. Int J Ind Chem $9: 1-14$

14. Zhao X, Yang L, Li X, Jia X, Liu L, Zeng J, Guo J, Liu P (2015) Functionalized graphene oxide nanoparticles for cancer cell-specific delivery of antitumor drug. Bioconjug Chem 26(1):128-136

15. Goenka S, Sant V, Sant S (2014) Graphene-based nanomaterials for drug delivery and tissue engineering. J Control Release 173:75-88

16. Rana VK, Choi MC, Kong JY, Kim GY, Kim MJ, Kim SH, Mishra S, Singh RP, Ha CS (2011) Synthesis and drug-delivery behavior of chitosan-functionalized graphene oxide hybrid nanosheets. Macromol Mater Eng 296(2):131-140

17. Ho LY, Dukjoon K, Sung LD (1997) Drug releasing characteristics of thermo- and $\mathrm{pH}$-sensitive interpenetrating polymer networks based on poly (N-isopropylacrylamide). J Appl Polym Sci 64(13):2647-2655

18. Wei L, Cai C, Lin J, Chen T (2009) Dual-drug delivery system based on hydrogel/micelle composites. Biomaterials 30(13):2606-2613

19. Kuritzky L, Samraj GP (2011) Enhanced glycemic control with combination therapy for type 2 diabetes in primary care. Diabetes Ther 2(3):162-177

20. Ma D, Tu K, Zhang L-M (2010) Bioactive supramolecular hydrogel with controlled dual drug release characteristics. Biomacromolecules 11(9):2204-2212

21. Manna U, Patil S (2009) Dual drug delivery microcapsules via layer-by-layer self-assembly. Langmuir 25(18):10515-10522
22. Aderibigbe BA, Mhlwatika Z (2016) Dual release kinetics of antimalarials from soy protein isolate-carbopol-polyacrylamide based hydrogels. J Appl Polym Sci 133(37):43918

23. Haslam DW, James WP (2005) Obesity. Lancet 366(9492):1197-1209

24. International Diabetes Federation (2017) IDF Diabetes Atlas, 8th edition. Accessed 12 Jun 2018

25. Reaven GM, Chen YD, Golay A, Swislocki AL, Jaspan JB (1987) Documentation of hyperglucagonemia throughout the day in nonobese and obese patients with noninsulin-dependent diabetes mellitus. J Clin Endocrinol Metab 64(1):106-110

26. McGarry JD (1992) What if Minkowski had been ageusic? An alternative angle on diabetes. Science 258(5083):766-770

27. Akash MSH, Rehman K, Liaqat A (2018) Tumor necrosis factoralpha: role in development of insulin resistance and pathogenesis of type 2 diabetes mellitus. J Cell Biochem 119(1):105-110

28. Akash MSH, Rehman K, Chen S (2013) Role of inflammatory mechanisms in pathogenesis of type 2 diabetes mellitus. J Cell Biochem 114(3):525-531

29. Rehman K, Akash MSH (2017) Mechanism of generation of oxidative stress and pathophysiology of type 2 diabetes mellitus: how are they interlinked? J Cell Biochem 118(11):3577-3585

30. Sies $H$ (2016) The concept of oxidative stress after 30 years. Biochemistry of oxidative stress. Springer, Berlin, pp 3-11

31. Ayeleso T, Ramachela K, Mukwevho E (2018) Aqueous-methanol extracts of orange-fleshed sweet potato (Ipomoea batatas) ameliorate oxidative stress and modulate type 2 diabetes associated genes in insulin resistant $\mathrm{C} 2 \mathrm{C} 12$ cells. Molecules 23(8):2058

32. Hurrle S, Hsu WH (2017) The etiology of oxidative stress in insulin resistance. Biomed J 40(5):257-262

33. Rehman K, Akash MSH (2016) Nutrition and diabetes mellitus: how are they interlinked? Crit Rev Eukaryot Gene Expr 26:4

34. Fève B, Bastard J-P (2009) The role of interleukins in insulin resistance and type 2 diabetes mellitus. Nat Rev Endocrinol 5(6):305

35. Hotamisligil G (2003) Inflammatory pathways and insulin action. Int J Obes 27(S3):S53

36. Moller DE (2000) Potential role of TNF- $\alpha$ in the pathogenesis of insulin resistance and type 2 diabetes. Trends Endocrinol Metab 11(6):212-217

37. Akash MSH, Shen Q, Rehman K, Chen S (2012) Interleukin-1 receptor antagonist: a new therapy for type 2 diabetes mellitus. J Pharm Sci 101(5): 1647-1658

38. Vance JE, Vance DE (2008) Biochemistry of lipids, lipoproteins and membranes. Elsevier, New York

39. Samuel Varman T, Shulman Gerald I (2012) Mechanisms for insulin resistance: common threads and missing links. Cell 148(5):852-871

40. Mosmann T (1983) Rapid colorimetric assay for cellular growth and survival: application to proliferation and cytotoxicity assays. J Immunol Methods 65(1-2):55-63

41. Denizot F, Lang R (1986) Rapid colorimetric assay for cell growth and survival. J Immunol Methods 89(2):271-277

42. Bruce D, Davis W, Casey G, Clarnette R, Brown S, Jacobs I, Almeida O, Davis T (2009) Severe hypoglycaemia and cognitive impairment in older patients with diabetes: the Fremantle Diabetes Study. Diabetologia 52(9): 1808

43. Petersen KF, Dufour S, Befroy D, Garcia R, Shulman GI (2004) Impaired mitochondrial activity in the insulin-resistant offspring of patients with type 2 diabetes. N Engl J Med 350(7):664-671

44. Patti ME, Butte AJ, Crunkhorn S, Cusi K, Berria R, Kashyap S, Miyazaki Y, Kohane I, Costello M, Saccone R (2003) Coordinated reduction of genes of oxidative metabolism in humans with insulin resistance and diabetes: potential role of PGC1 and NRF1. Proc Natl Acad Sci 100(14):8466-8471 
45. Dobbins RL, Szczepaniak LS, Bentley B, Esser V, Myhill J, McGarry JD (2001) Prolonged inhibition of muscle carnitine palmitoyltransferase-1 promotes intramyocellular lipid accumulation and insulin resistance in rats. Diabetes 50(1):123-130

46. Satoh J-I, Kawana N, Yamamoto Y (2013) Pathway analysis of ChIP-Seq-based NRF1 target genes suggests a logical hypothesis of their involvement in the pathogenesis of neurodegenerative diseases. Gene Reg Syst Biol 7:S13204

47. Mora S, Pessin JE (2000) The MEF2A isoform is required for striated muscle-specific expression of the insulin-responsive GLUT4 glucose transporter. J Biol Chem 275(21):16323-16328

48. Baar K, Song Z, Semenkovich CF, Jones TE, Han D-H, Nolte LA, Ojuka EO, Chen M, Holloszy JO (2003) Skeletal muscle overexpression of nuclear respiratory factor 1 increases glucose transport capacity. FASEB J 17(12):1666-1673
49. Carvalho E, Kotani K, Peroni OD, Kahn BB (2005) Adiposespecific overexpression of GLUT4 reverses insulin resistance and diabetes in mice lacking GLUT4 selectively in muscle. Am J Physiol Endocrinol Metab 289(4):E551-E561

50. Sheikhbahaie F, Amini M, Gharipour M, Aminoroaya A, Taheri $\mathrm{N}$ (2016) The effect of hydroxychloroquine on glucose control and insulin resistance in the prediabetes condition. Adv Biomed Res $5: 145$

Publisher's Note Springer Nature remains neutral with regard to jurisdictional claims in published maps and institutional affiliations. 